\title{
A floristic-ecological classification of the shrublands of the dry Bolivian Altiplano
}

\author{
Gonzalo Navarro \& José Antonio Molina*
}

\begin{abstract}
Aims: To identify shrubland types of the Bolivian Altiplano based on their floristic composition and on ecological factors. Location: Central and southern Bolivian Altiplano (Bolivia, central-western South America). Methods: Vascular plants were recorded in a field survey of 101 relevés $\left(10 \mathrm{~m}^{2}\right)$. Relevés were subjected to hierarchical agglomerative classification to define numerical vegetation groups. Classification techniques were based on the $\beta$-flexible linkage method $(\beta=-0.25)$ with Sørensen distance. The highest crispness values defined the level of the main number of clusters identified. Diagnostic species were identified by means of the phi coefficient of fidelity. Canonical Correspondence Analysis, the Kruskal-Wallis test and a Z test were performed to assess the key ecological drivers of diversity in the Altiplano shrubland vegetation. Results: Based on numerical analyses of phytosociological relevés, our work proposes four vegetation types of shrublands in the dry central and southern Bolivian Altiplano. They correspond to the following: tolillares - thickets of Fabiana densa - of the central-southern Altiplano with Junellia seriphioides; tolillares of the central-northern Altiplano with Lobivia pentlandii; lampayares - thickets of Lampayo castellani - with Parastrephia quadrangularis; and tolares - thickets of Parastrephia sp. pl. - with Parastrephia lepidophylla and Junellia minima. The bioclimatic variables were the ones best explaining the distribution patterns of the shrubland vegetation in the dry Bolivian Altiplano. Specifically, they separate the tolillares of the central-northern Altiplano with Lobivia pentlandii - at localities with a higher annual precipitation, annual ombrothermic index, and ombrothermic index of the wettest quarter - from the tolillares of the central-southern Altiplano with Junellia seriphioides. These bioclimatic gradients also position lampayares at localities with a lower than average value of annual precipitation, annual ombrothermic index, and ombrothermic index of the wettest quarter. Significant differences were found when comparing the topographic position, the degree of soil drainage and the frequency of flooding between the vegetation of tolillares on the one hand, and the vegetation of lampayares and tolares, on the other. Lampayares were exclusively related to sandy soils. Conclusions: Our four groups characterize variation within the habitat and elucidate bioclimatic gradients and soil features with related habitats. This knowledge could provide basic information on the vulnerability of different Altiplano shrubland habitats to climatic fluctuations, as this area is highly vulnerable to extreme periods of drought associated with the regional effects of climate change as well as to anthropogenic factors.
\end{abstract}

Keywords: Andean region; diagnostic species; Fabiana densa; Lampayo castellani; Lobivio ferocis-Fabianion densae; numerical classification; orotropical climate; Parastrephia lepidophylla; Parastrephion lepidophyllae; plant-community type; shrubland.

Taxonomic reference: Bolivia Catalogue (2014; http://www.tropicos.org/Project/BC).

Syntaxonomic reference: Navarro (1993, 2002, 2011).

Abbreviations: $\mathrm{CCA}=$ Canonical correspondence analysis; Io $=$ annual ombrothermic index; Iod $=$ ombrothermic index of the driest quarter; Iow $=$ ombrothermic index of the wettest quarter; $\mathrm{Tw}_{\mathrm{w}}=$ mean temperature of the wettest quarter.

Submitted: 30 September 2017; first decision: 28 December 2017; accepted: 21 October 2018

Co-ordinating Editor: Florian Jansen

\footnotetext{
${ }^{*}$ Corresponding author's address: Departamento de Biodiversidad, Ecología y Evolución, Facultad de Ciencias Biológicas, Universidad Complutense de Madrid, c/José Antonio Novais, 12, 28040-Madrid, Spain; E-mail: jmabril@ucm.es. Complete addresses of all authors can be found at the bottom of the paper.
} 


\section{Introduction}

The Bolivian Altiplano is, after the Tibetan plateau, the largest and highest plateau in the world. It belongs to the Central Andean Dry Puna ecoregion, a very dry highelevation montane territory whose flora and fauna are highly adapted to this extreme environment (Olson \& Dinerstein 1998). The Bolivian Altiplano corresponds to the Altiplanean biogeographic province, where plant genera such as Lampayo (Verbenaceae), Parastrephia (Asteraceae) and Fabiana (Solanaceae) have their centre of diversity and form the core of the shrubland plant communities, the main vegetation matrix in the Bolivian Altiplano (Navarro 1993, 2002, 2011). Our study focused on these formations, which constitute the natural potential vegetation in large areas with dry and semi-arid climates, and are also affected by strong thermal inversions in the dry season. They form part of the seral vegetation of Polylepis woodlands only on mountainous slopes in mountain ranges in the eastern and western Altiplano, with a more humid climate and an absence of very intense frost in peripheral mountains (Navarro et al. 2005). The absence of Polylepis forest in the Altiplanic plain might be due to the bad drainage and salinity of the soils, as well as to the strong thermal inversions to which these areas are subjected.

Central Andean shrublands have been widely studied in Argentina (Fries 1905; Cabrera 1957, 1971, 1994; Ruthsatz 1977; Martínez Carretero 1995). In Bolivia, some types of Altiplanean shrubland have been phytosociologically studied by Navarro (1993, 2002, 2011). They have also been described in a general or applied form, for example in relation to livestock, firewood or their medicinal value (Lara \& Alzérreca 1982; Beck 1985; Ibisch et al. 2003; García \& Beck 2006, among others). Nevertheless, there is still a need for an updated floristic-ecological classification of Andean shrubland communities. This basic knowledge is particularly important for any environmental management in the Altiplano, and particularly in the Bolivian territory which is more sensitive and vulnerable to climate change (Rigoberto et al. 2007), and where the specific forecast is for a sharp rise in the mean annual temperature and a greater rainfall deficit.

The main aim of this work is to provide a comprehensive overview of the floristic-ecological diversity of the shrublands in the dry Bolivian Altiplano. Our study is based on our own original floristic relevés collected on these shrublands. The specific aims of this work are: (1) to organize floristic relevés into discrete floristic groups and define their diagnostic species; and (2) to determine the floristic relationships between these groups and the major environmental gradients that best explain the variability of the floristic composition.

\section{Study site}

The Altiplano or Andean plateau, extending from SW Peru over W Bolivia to NE Chile and NW Argentina, reaches its greatest extension in Bolivia, where it has an average width of $150-220 \mathrm{~km}$ and elevation of c. $3700 \mathrm{~m}$ a.s.l. The greatest width $(220 \mathrm{~km})$ is found around latitude $18^{\circ} 30^{\prime} \mathrm{S}$ in Oruro and Poopó Lake. Between the hills, mountain ranges and plains of the Altiplano there are ample detrital glacis (gentle pediment slope cut across bedrock in drylands) that connect, in this case, the mountainous slopes with extensive saline depressions containing large lakes and salt flats. The lithology of the Altiplano plain is predominantly composed of fine Quaternary sediments (silt, clay and fine sands) with a fluvial-lacustrine origin, and extensive windswept areas that may form fields of sand dunes that locally attain considerable extensions. In contrast, the various mountain ranges and numerous hills interspersed in the plains of the Altiplano are formed from Paleozoic (shales, slates, sandstones) and Tertiary (sandstones, conglomerates) rocky materials (GEOBOL 1994; Suárez-Soruco 2000).

Calcareous areas can occasionally be found surrounding several areas of the Altiplano salt flats, somewhat raised above their present level. They correspond to karstified lacustrine algal terraces originating in the ancient large lakes that covered much of the central Altiplano region in the interglacial periods of the Pleistocene-Holocene era, from around 30,000 years b.p. (Minchin and Tauca Quaternary lacustrine phases). These calcareous lacustrine terraces mark the level reached by the waters of these paleolakes (Argollo 1994; Sánchez-Saldías \& Fariña 2014; Chepstow-Lusty et al. 2005).

The Bolivian Altiplano has a cold, dry, predominantly high-mountain tropical climate, with high insolation and evapotranspiration, and strong winds almost all year round. Mean annual temperatures $(\mathrm{T})$ generally range from around $5^{\circ} \mathrm{C}$ to $9^{\circ} \mathrm{C}$ (Vicente-Serrano et al. 2016). Average minimum temperatures in the coldest month of the year (June or July) range from $-3{ }^{\circ} \mathrm{C}$ to $-12{ }^{\circ} \mathrm{C}$. Rainfall varies from approximately $400-500 \mathrm{~mm} /$ year in the north and east to $120-280 \mathrm{~mm} /$ year in the south and west. There is a high interannual variability in rainfall, with differences in total rainfall of between 80 and over $700 \mathrm{~mm}$ in dry and wet years. A characteristic climate phenomenon in the dry season (May to September) is the strong thermal inversion in several zones of the plateau, especially those located adjacent to or near the mountain ranges surrounding the Altiplano. According to RivasMartínez et al. (2011), the central Altiplano in Bolivia has a tropical dry xeric bioclimate, while the southern Altiplano has a tropical semi-arid xeric bioclimate.

In the Bolivian Altiplano, two major shrubland types are recognized: thickets of Fabiana densa known as tolillares and plant communities dominated by species of the genus Parastrephia (e.g. Parastrephia lepidophylla) 
known as tolares (Navarro 1993, 2002, 2011). Both the tolillares and tolares vegetation types are largely in geocatenal contact throughout the Bolivian Altiplano. On sandy dunes, the shrublands are characterized by Lampayo castellani and constitute the vegetation known as lampayares.

\section{Material and methods}

We compiled data from our own unpublished relevés (made from 1989 to 2016) corresponding to tollillares, tolares and lampayares on extensive xeric areas in the whole central and southern Bolivian Altiplano (Fig. 1). Sample plots were selected according to these physiognomicecological formations. Floristic data were recorded for each plot $\left(10 \mathrm{~m}^{2}\right)$, and the cover of each species was estimated using the Braun-Blanquet (1979) scale. We also recorded soil features such as drainage, flooding, effervescence, salinity and texture. We used USDA (2017) classes to describe drainage, flooding frequency, effervescence and texture, and our own scale to describe salinity

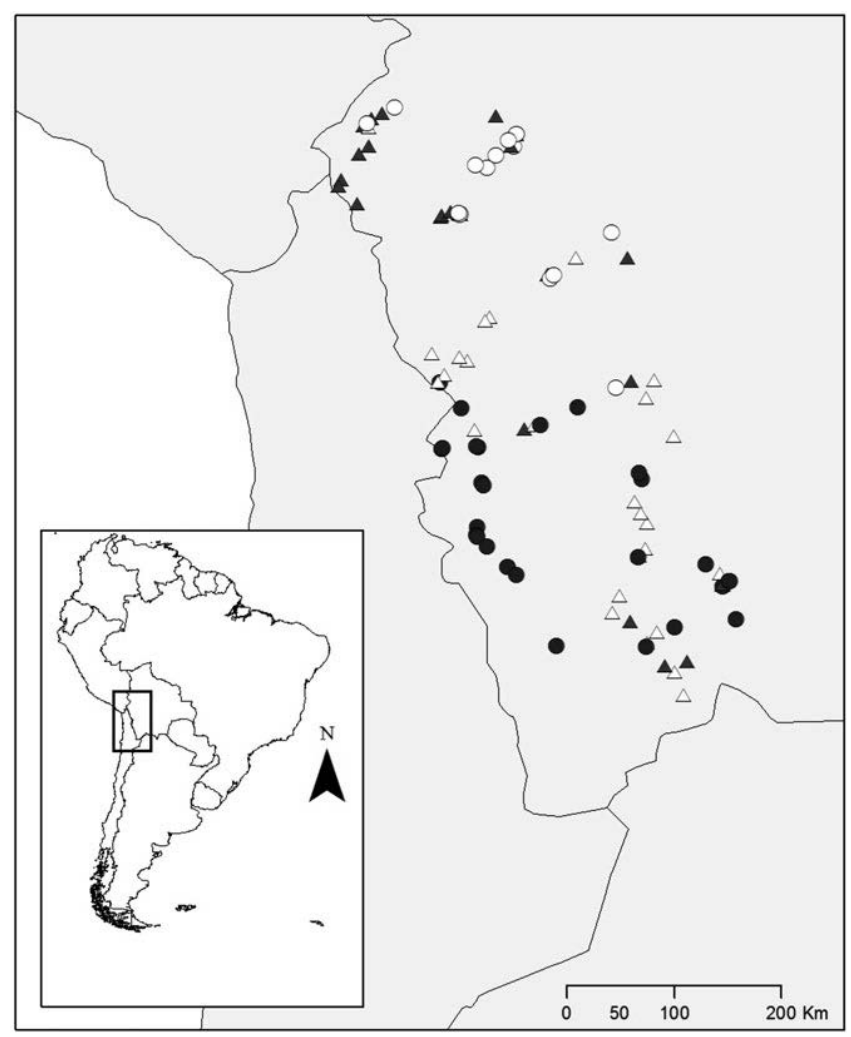

Fig. 1. Location of the study area (rectangle) showing the locations of the samples. Symbols correspond to groups in Table 1. Tolillares of the central-southern Altiplano (Group A), black circles; tolillares of the central-northern Altiplano (group B), white circles; lampayares (group C), white triangles; tolares (group D), black triangles. (see footnote in Table 2). The position of the plot in the geocatena was documented according to the following scale: 1 = hill; 2 = high glacis; $3=$ middle glacis; $4=$ low glacis; and 5 = fluvio-lacustrine and alluvial plains.

The relevés were gathered, reviewed, and sorted in a table, which was subjected to analysis using numerical methods. Floristic data were revised, updated and corrected for any obvious misidentifications. The taxonomic nomenclature of the species follows the Bolivia Catalogue (2014; http://www.tropicos.org/Project/BC). An agglomerative classification method was first applied to the dataset using the $\beta$-flexible linkage method $(\beta=-0.25)$ with Sørensen distance. Cover values were square-root transformed in order to reduce the importance of dominant species (Van der Maarel 1979). The crispness of the classification was checked using the method in Botta-Dukát et al. (2005). This method revealed the highest crispness at the level of two clusters (58.4) followed very closely at the level of four clusters (58.3), which was the option we chose since it explained four instead of two vegetation units in detail. A synoptic table was created with constancy values and diagnostic species. To define diagnostic species for each vegetation type, the phi coefficient of fidelity $(\Phi)$ was used (Chytrý et al. 2002). We show only the diagnostic species with values of the phi coefficient of association $>0.20$ for at least one cluster, and with a statistically significant affinity at the probability level $<0.001$ according to Fisher's exact test.

A Canonical Correspondence Analysis (CCA) was also performed to specifically assess the relationship between species composition and bioclimate. The following selected bioclimatic data were obtained from the WorldClim model (Fick \& Hijmans 2017): total annual precipitation $(\mathrm{P})$, mean annual temperature $(\mathrm{T})$, mean temperature of the wettest quarter ( $\mathrm{Tw})$, mean temperature of the driest quarter $(\mathrm{Td})$, precipitation of the wettest quarter $(\mathrm{Pw})$ and precipitation of the driest quarter $(\mathrm{Pd})$. The following calculated indexes are also included in the analysis: annual ombrothermic index (Io $=\mathrm{P} / \mathrm{T}$ ), ombrothermic index of the wettest quarter (Iow $\left.=\mathrm{Pw}_{\mathrm{w}} / \mathrm{Tw}\right)$, and ombrothermic index of the driest quarter $(\operatorname{Iod}=\mathrm{Pd} / \mathrm{Td})$. A Monte Carlo test was performed to determine the statistically significant environmental factors. Numerical analyses were done with the JUICE 7.0 (Tichý 2002) and CANOCO 4.5 programs (Microcomputer Power, Ithaca, NY, US). The Kruskal-Wallis test was used to compare differences in soil features (drainage, flooding, effervescence, and salinity) and topographic position (hill, glacis, fluvial terrace) among groups of vegetation resulting from the numerical classification (A-D). The Chi-square test and $\mathrm{Z}$ test with Bonferroni corrections were used to assess differences on textures among vegetation groups. Analyses were carried out using SPSS v.25 software. 


\section{Results}

\section{Classification and ordination analyses}

The 101 relevés were arranged in four major groups (A, B, $\mathrm{C}$ and $\mathrm{D}$ ) according to the crispness of the classification (Fig. 2, Table 1). Group A included 28 relevés and is characterized by a high constancy (>75\%) of Fabiana densa and Junellia seriphioides, which along with Baccharis boliviensis are the diagnostic species with the highest phi scores. Other species with high constancies in this group and also widespread in the Altiplano were Baccharis tola and Adesmia spinosissima. It is worth noting the species that are limited to group A, including Chuquiraga atacamensis, Adesmia horrida, Atriplex imbricata, Fabiana squamata, Trichocereus atacamensis and Lophopappus cuneatus. This group encompasses mainly tolillares shrublands distributed in the central-southern Altiplano (Fig. 1, Fig. 3A). Group B shows the northern Altiplanean endemic Lobivia pentlandii as the diagnostic species with the highest fidelity and high constancy values, in addition to other widely distributed Altiplanean species such as Jarava ichu and Aristida asplundii (Table 1). Other species with high constancy are Baccharis tola, Cumulopuntia boliviana, Tetraglochin cristatum, Adesmia spinosissima and Fabiana densa, among others. This group encompasses 15 relevés and includes tolillares mainly occurring in the central-northern Altiplano (Fig. 1, Fig. 3B). The diagnostic species with the highest fidelity and a high constancy in Group C were Lampayo castellani and Parastrephia quadrangularis (Table 1). Parastrephia lepidophylla also attains a high constancy. This group includes lampayares and it is found in central and southern Altiplano (Fig. 3C). Group $\mathrm{D}$ contains - like the previous group - 29 relevés and reveals Junellia minima, Mublenbergia fastigiata, Distichlis bumilis and Parastrephia lucida as diagnostic species with the highest fidelity scores (Table 1). It also has a high constancy of Parastrephia lepidophylla. This group includes the tolares found throughout the Altiplano (Fig. 1; Fig. 3D).

The CCA ordination (Fig. 4) applied to shrublands on the dry Bolivian Altiplano (Groups A, B, C and D) and nine bioclimatic variables showed that four of these features (P, Iow, Io and Tw) were significant $(p<0.05)$ in the Monte Carlo test. Tolillares vegetation was segregated in two groups (Group A and Group B) along axis 1, which in turn is highly correlated with P, Io and Iow. Tolillares in Group A (black circles) were mainly positioned in the left part of the diagram, so they can be inferred to be mainly characteristic of localities with lower than average values of P, Io and Iow. This group is centered on diagnostic species such as Fabiana densa, Junellia seriphioides and Baccharis boliviensis. The tolillares of the centralnorthern Altiplano are found in opposite positions (Group B, white circles), and are mostly located in the lower right quadrant of the diagrams in places with lower than average values of Tw. In these positions occur diagnostic species such as Lobivia pentlandii, Jarava ichu and Aristida asplundii. Lampayares shrublands (Group C, white triangles) are mostly grouped in the upper left quadrant in places with lower than average values of $\mathrm{P}$, Io and Iow, and higher than average Tw. This group is centered on diagnostic species such as Lampayo castellani and Parastrephia quadrangularis. To complete the picture, tolares (Group D, black triangles) are mainly positioned in the right part of the diagram, centered on diagnostic species such as Junellia minima, Mublenbergia fastigiata and Distichlis humilis.

Table 2 shows mean values and variance of ordinal edaphic variables in each vegetation group. No significant differences were found between group $\mathrm{A}$ and $\mathrm{B}$ nor between group $\mathrm{C}$ and $\mathrm{D}$ for any of the edaphic factors.

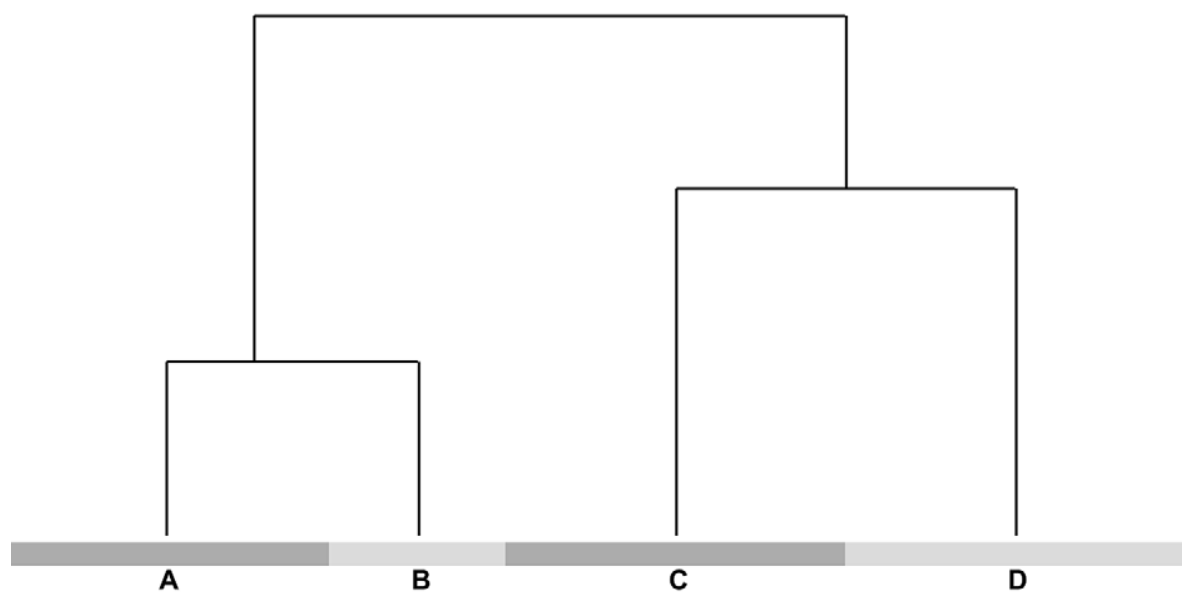

Fig. 2. Dendrogram of $\beta$-flexible clustering analysis applied to the shrublands of the dry Bolivian Altiplano data-set, with 101 relevés and 73 species. Cluster groups (A-D) correspond to those in the synoptic table (Table 1). 
Table 1. Synoptic table of the shrublands of the dry Bolivian Altiplano showing the constancy values of species in each of the four vegetation units (columns) obtained in the classification analysis. Only species with a constancy $>25 \%$ in at least one group are included. Grey background colour indicates diagnostic species with phi coefficient $>0.20$. Mean cover is indicated as superscript. E subscript after the name of the species means that it is an endemic plant to Bolivian Altiplano.

\begin{tabular}{lcccc}
\hline Higher-Level Cluster-Groups & A & B & C & D \\
\hline $\mathrm{N}^{\circ}$ of relevés & 28 & 15 & 29 & 29 \\
\hline
\end{tabular}

Characteristic and Differential species

High Andean shrublands (Parastrephio lepidophyllae-Fabianetea densae)

Fabiana densa

Parastrephia quadrangularis

Baccharis tola

Parastrephia lepidophylla

Cumulopuntia boliviana

Frankenia triandra

Adesmia spinosissima

Ephedra rupestris

Festuca orthophylla

Nasella nardoides

Astragalus arequipensis

Jarava leptostachya

\begin{tabular}{|c|c|c|c|}
\hline $100^{3}$ & 60 & 28 & 7 \\
\hline 36 & 13 & $72^{2}$ & 21 \\
\hline 75 & 100 & 55 & 45 \\
\hline 7 & 73 & 93 & 86 \\
\hline 32 & 87 & 10 & 24 \\
\hline 25 & 27 & 66 & 48 \\
\hline 75 & 73 & 45 & 10 \\
\hline 50 & 53 & 31 & 17 \\
\hline 11 & 27 & 52 & 62 \\
\hline 21 & 7 & 48 & 34 \\
\hline 4 & 33 & 3 & 7 \\
\hline 29 & 13 & 7 & 3 \\
\hline $86^{2}$ & . & 17 & . \\
\hline $64^{3}$ & 13 & 14 & . \\
\hline . & $80^{1}$ & 3 & 7 \\
\hline 39 & 7 & 3 & 3 \\
\hline 36 & 60 & 7 & . \\
\hline 32 & 13 & 3 & . \\
\hline 21 & . & 7 & 3 \\
\hline 43 & 7 & . & . \\
\hline 29 & 13 & . & . \\
\hline 25 & 20 & . & . \\
\hline 29 & . & 3 & . \\
\hline 25 & . & 7 & . \\
\hline 25 & . & 3 & . \\
\hline 32 & . & . & . \\
\hline 29 & . & . & . \\
\hline 29 & . & . & . \\
\hline 25 & . & . & . \\
\hline 25 & . & . & . \\
\hline 25 & . & . & . \\
\hline . & 27 & . & . \\
\hline 7 & . & $66^{3}$ & 3 \\
\hline . & 27 & 10 & $86^{2}$ \\
\hline . & 27 & 3 & $59^{2}$ \\
\hline . & 7 & 10 & $34^{2}$ \\
\hline . & . & 21 & $45^{1}$ \\
\hline . & . & 7 & 28 \\
\hline
\end{tabular}

Tolillares communities (Lobivio ferocis-Fabianion densae)

Junellia seriphioides

Baccharis boliviensis

Lobivia pentlandii

Cumulopuntia chichensis ${ }_{\mathrm{E}}$

Airampoa ayrampo

Senecio potosianus $\mathrm{E}$

Jarava plumulosa

Echinopsis longispina

Cherdosoma jodopappa

Nassella arcuata

Lycium chanar

Maihueniopsis nigrispina ${ }_{\mathrm{E}}$

Chuquiraga acanthophylla

Chuquiraga atacamensis

Adesmia horrida

Trichocereus atacamensis

Atriplex imbricata

Fabiana squamata

Lophopappus cuneatus

Portulaca perennis

Tolares and Lampayares communities (Parastrephion lepidophyllae)

Lampayo castellani

Junellia minima

Muhlenbergia fastigiata

Distichlis humilis

Parastrephia lucida

Deyeuxia curvula 
Table 1. cont.

\begin{tabular}{lcccc}
\hline Higher-Level Cluster-Groups & A & B & C & D \\
\hline No of relevés & $\mathbf{2 8}$ & $\mathbf{1 5}$ & $\mathbf{2 9}$ & $\mathbf{2 9}$ \\
\hline Widely distributed species & & & & \\
Jarava ichu & 29 & $100^{2}$ & 14 & 41 \\
Aristida asplundii & 14 & $73^{2}$ & 10 & 7 \\
Tetraglochin cristatum & 29 & 87 & 72 & 66 \\
Bouteloua simplex & 11 & 27 & 31 & 10 \\
Muhlenbergia peruviana &. & 27 & 7 & 7 \\
Nassella meyeniana &. & 33 & 3 & 17 \\
Adesmia miraflorensis & 7 & 53 &. &. \\
\hline
\end{tabular}
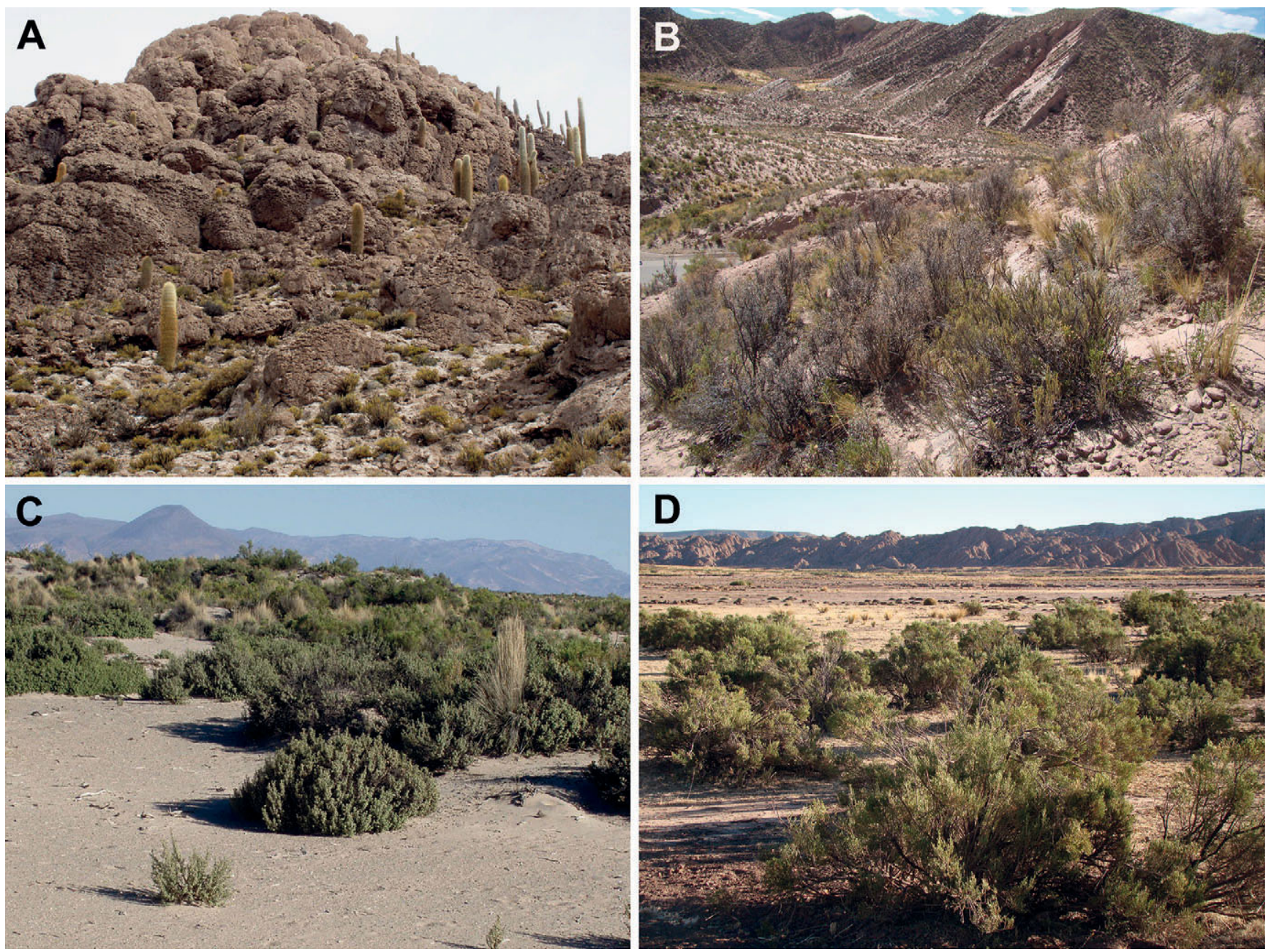

Fig. 3. Photographs showing the plant-landscape physiognomy of shrublands of the dry Bolivian Altiplano. A. Tolillares of the central-southern Altiplano with Lycium chanar and Atriplex imbricata (Group A) in margins of the north of Salar de Coipasa, between Sabaya and Coipasa (Oruro). B. Tolillares of the central-northern Altiplano with Lobivia pentlandii and Parastrephia lepidophylla (Group B), between Umala and Desaguadero River (Departmento de La Paz). C. Lampayares of Lampayo castellani with Parastrephia quadrangularis (Group C) in sand dunes in the west of the Altiplano (Oruro: Sabaya to Todos Santos). D. Tolares with Parastrephia lepidophylla and Frankenia triandra (Group D) in Calacoto (Departamento de La Paz). 


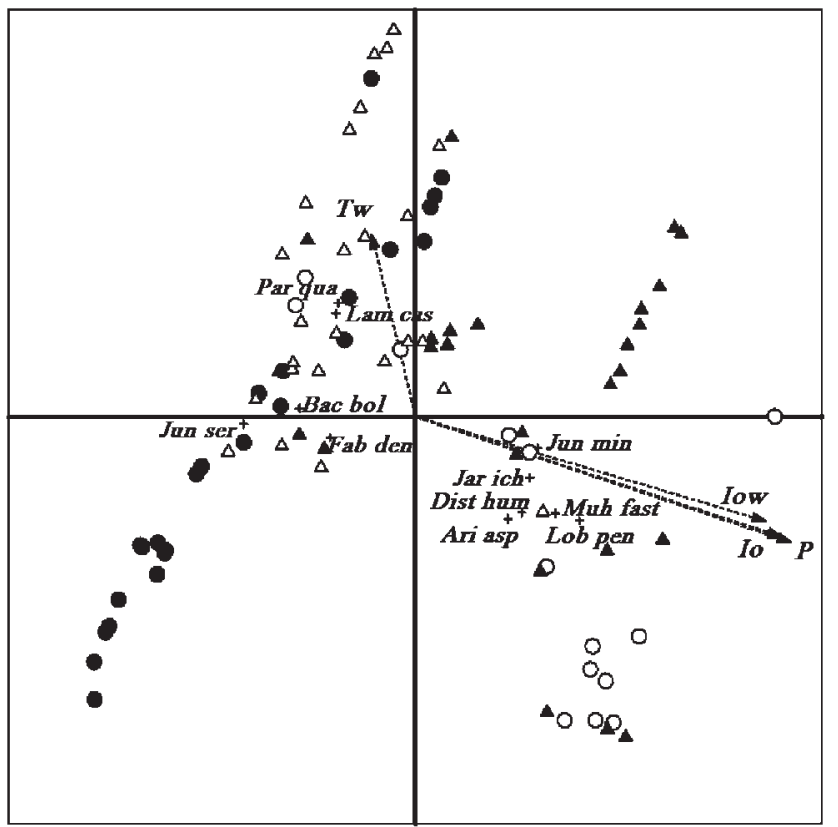

Fig. 4. Species-conditional biplot of the shrublands of the dry Bolivian Altiplano based on a CCA. Symbols correspond to those in Figure 1. The eigenvalues of axis 1 (horizontal) and axis 2 (vertical) are 0.40 and 0.19 , respectively. The displayed environmental variables are those significant in the Monte Carlo test. $\mathrm{P}=$ annual rainfall, $\mathrm{Tw}=$ mean temperature of the wettest quarter, $\mathrm{l} 0=$ annual ombrothermic index lo = $\mathrm{P} / \mathrm{T}$ ), and low = ombrothermic index of the wettest quarter $($ low $=\mathrm{Pw} / \mathrm{Tw}$ ). Plant abbreviations of the diagnostic species are as follows: Ari asp, Aristida asplundii; Bac bol, Baccharis boliviensis; Dist hum, Distichlis humilis; Fab den, Fabiana densa; Jar ich, Jarava ichu; Jun min, Junellia minima; Jun ser, Junellia seriphioides; Lam cas, Lampayo castellani; Lob pen, Lobivia pentlandii; Muh fast, Muhlenbergia fastigiata; Par qua, Parastrephia quadrangularis.
However, significant relationships were found when comparing the overall tolillares vegetation (groups $\mathrm{A}$ and $\mathrm{B}$ ) with that formed by lampayares and tolares (groups C and D) in terms of topography, soil flooding and soil drainage (Kruskal-Wallis test, $p<0.001$ ). Tolillares occur on better-drainage and less-flooded soils than lampayares and tolares. Topographically, tolillares occupy mostly mountain slopes and high glacis, whereas tolares and lampayares are mostly found in alluvial plain and low glacis. The cross tabulation resulting from $\mathrm{Z}$ test showed a significant relationship between lampayares (group C) and sandy texture soils (Table 3 ).

\section{Discussion}

\section{Vegetation units}

Vegetation is often regarded as a very good surrogate descriptor of habitats and ecosystems (Jennings et al. 2009). In the shrublands of the dry Bolivian Altiplano, agglomerative classification identified two vegetation units at the higher level (namely tolillares - Groups A and B -, lampayares - Group C - and tolares - Group D). These numerical results support the major vegetation units of Lobivio ferocis-Fabianion densae (Groups A and B) and Parastrephion lepidophyllae (Groups C and D), described as alliances by Navarro (1993). Along with the alliance Diplostephio meyenii-Fabianion ramulosae (Luebert \& Gajardo 2000; Luebert \& Gajardo 2005), they all constitute the synopsis of the shrubland vegetation of the dry Altiplano through SW Peru, W Bolivia, NE Chile and NW Argentina. These alliances are encompassed in the phytosociological class and order of Parastrephio lepido-

Table 2. Mean values and variance of the topographic position and edaphic variables in each of the 4 vegetation units (A-D) obtained from clustering analysis.

\begin{tabular}{lllllllll}
\hline Higher-Level Cluster-Group & \multicolumn{2}{l}{ Group A } & \multicolumn{2}{l}{ Group B } & \multicolumn{2}{l}{ Group C } & \multicolumn{2}{l}{ Group D } \\
\hline Edaphic variables (range) & Mean & Variance & Mean & Variance & Mean & Variance & Mean & Variance \\
\hline Topography (1-5) & 1.36 & 0.386 & 1.33 & 0.667 & 3.59 & 1.894 & 3.66 & 2.948 \\
Drainage (1-5) & 1.75 & 0.491 & 2.20 & 0.886 & 2.62 & 1.744 & 3.55 & 1.685 \\
Flooding (0-5) & 0.07 & 0.069 & 0.13 & 0.124 & 0.97 & 1.963 & 1.76 & 2.833 \\
Effervescence (1-5) & 2.07 & 1.772 & 1.87 & 0.981 & 2.17 & 1.291 & 2.10 & 1.239 \\
Salinity (0-5) & 0.39 & 0.396 & 0.40 & 0.257 & 0.69 & 1.293 & 0.86 & 1.195 \\
\hline
\end{tabular}

Topography class (1-5): 1 = Mountain slope; 2 = High glacis; 3 = Middle glacis; 4 = Low glacis; 5 = Fluvio-lacustrine and alluvial plains. Drainage class (USDA 2017): 5 = Very poorly drained; 4 = Somewhat poorly drained to poorly drained; $3=$ Moderately well drained; $2=$ Well drained; 1 = Excessively to somewhat excessively drained. Flooding frequency class (USDA 2017): $0=$ None; $1=$ Very rare; 2 = Rare; $3=$ Occasional; 4 = Frequent; 5 = Very frequent. Effervescence class (USDA 2017): 1 = Non effervescent; 2 = Very slightly effervescent; 3 = Slightly effervescent; $4=$ Strongly effervescent; $5=$ Violently effervescent. Salinity class: $0=$ total absence of efflorescence; $1=$ very thin or patchy efflorescence 2 = thin and discontinuous salt crust; 3 = Thin salt crust unevenly spread over the surface of the soil; $4=$ moderately coarser almost continuous crust; 5 = medium thick continuous surface crust. 
Table 3. Contingency table for soil texture classes and vegetation groups.

\begin{tabular}{llllll}
\hline Higher-Level Cluster-Group & Group A & Group B & Group C & Group D \\
\hline Texture 1 & Count & $0_{\mathrm{a}}$ & $1_{\mathrm{a}}$ & $0_{\mathrm{a}}$ & $5_{\mathrm{a}}$ \\
& $\%$ & $0.0 \%$ & $6.7 \%$ & $0.0 \%$ & $17.2 \%$ \\
Texture 2 & Count & $1_{\mathrm{a}}$ & $3_{\mathrm{a}}$ & $7_{\mathrm{a}}$ & $7_{\mathrm{a}}$ \\
& $\%$ & $3.6 \%$ & $20.0 \%$ & $24.1 \%$ & $24.1 \%$ \\
Texture 3 & Count & $6_{\mathrm{a}, \mathrm{b}}$ & $4_{\mathrm{a}, \mathrm{b}}$ & $1_{\mathrm{b}}$ & $11_{\mathrm{a}}$ \\
& $\%$ & $21.4 \%$ & $26.7 \%$ & $3.4 \%$ & $37.9 \%$ \\
Texture 4 & Count & $21_{\mathrm{a}}$ & $7_{\mathrm{a}, \mathrm{b}}$ & $9_{\mathrm{b}}$ & $6_{\mathrm{b}}$ \\
& $\%$ & $75.0 \%$ & $46.7 \%$ & $31.0 \%$ & $20.7 \%$ \\
Texture 5 & Count & $0_{\mathrm{a}}$ & $0_{\mathrm{a}}$ & $12_{\mathrm{b}}$ & $0 \mathrm{a}$ \\
& $\%$ & $0.0 \%$ & $0.0 \%$ & $41.4 \%$ & $0.0 \%$ \\
\hline Total & Count & 28 & 15 & 29 & 29 \\
& $\%$ & $100.0 \%$ & $100.0 \%$ & $100.0 \%$ & $100.0 \%$ \\
\hline
\end{tabular}

Texture class (1-5): 1 = clayey; 2 = silty; 3 = loam; 4 = loam-sandy; 5 = sandy

phyllae-Fabianetea densae and Parastrephietalia lepidophyllae, respectively (Navarro 2002).

A subsequent step in our cluster analysis split the vegetation matrix into the four groups defined in the results $(\mathrm{A}, \mathrm{B}, \mathrm{C}, \mathrm{D})$, in which diagnostic species were identified in each group, mostly with high constancy (Table 1). They can therefore be identified as subunits maybe sub-alliances - each containing one or more associations or community types that have been described previously (Navarro 1993) or have yet to be described. These subunits, which are named in relation to dominant and diagnostic species, correspond to the following: tolillares - thickets of Fabiana densa - of the centralsouthern Altiplano with Fabiana densa and Junellia seriphioides (Group A), tolillares of the central-northern Altiplano with Lobivia pentlandii (Group B), lampayares of Lampayo castellani with Parastrephia quadrangularis (Group C), and tolares with Parastrephia lepidophylla and Junellia minima (Group D). Phytosociological associations already described in the Bolivian Altiplano are the Lobivio pentlandii-Fabianetum densae and Gutierrezio gillesiiVerbenetum seriphioidis within the Lobivio ferocis-Fabianion densae alliance; and the Mublenbergio fastigiataeParastrephietum lepidophyllae and Acantholippio hastulatae-Lampayoetum castellani within the Parastrephion lepidophyllae alliance (Navarro 1993).

\section{Ecological patterns and habitat conservation}

Both climate and soil have been identified as major drivers in montane shrubland distribution around the world (e.g. Li et al. 2016). Our study focuses on the shrublands of the dry Bolivian Altiplano and reveals bioclimatic fac- tors as being the most important variables differentiating floristic composition. Specifically, annual precipitation, annual ombrothermic index and ombrothermic index of the wettest quarter clearly distinguished the distribution of the tolillares groups, positioning the tolillares of $\mathrm{LO}^{-}$ bivia pentlandii in less dry areas. Besides, lampayares were associated to drier and warmer areas in which the climatic conditions favor the movement and deposit of the sand to which the lampayares is related. The ombrothermic index (Io) has been observed to be an important factor to distinguish other wooded habitat types in the high Andes, such as the Bolivian Polylepis forest (Navarro et al. 2005).

Our study also related soil factors to vegetation types. In particular, tolillares are chiefly found in hillsides on well-drainage soils and little or none prone to flooding. On the other hand, lampayares and tolares occur in low glacis and plains on soils with poorer drainage and more susceptible to flooding. Statistical analyses also revealed that lampayares are closely related to sandy soils. These findings support previous observational hypotheses $(\mathrm{Na}-$ varro 1993, 2002) about the ecology of the dry Altiplanean shrublands, which linked tolillares to coarse-textured non-flooded soils, lampayares to windswept surfaces and sand dunes and tolares to fine-textured substrates that are poorly drained or subject to flooding. In light of all this, the tolillares constitute zonal vegetation in equilibrium with the climate, which makes possible a spatial segregation between the northern tolillares in areas with more humid climate - and the southern ones - in areas with drier climate. Meanwhile, tolares and lampayares correspond to azonal (soil-dependent) vegetation, being therefore distributed in favourable substrates throughout the Altiplano. 
The projected climate changes in tropical South America at the end of the $21^{\text {st }}$ century are dominated by a significant warming and by a general decrease in winter (June-August) precipitation (Urrutia \& Vuille 2009). Future climate change will lead not only to an upslope but also to a downslope expansion for the dry Andean biomes (Tovar et al. 2013). In the coming scenario of higher temperatures and lower rainfall, the habitats related to the northern and relatively more humid tolillares with Lobivia pentlandii are probably the most threatened due to their connection to wetter climates. On the other hand, the tolillares are considered xerophytic vegetation while the tolares are considered phreatophytic vegetation. The projected decrease in rainfall in the Altiplano area will have an impact on the recharge of the aquifers on which the tolares depend. The monitoring of the extension of the tolillares versus the tolares can be a good indicator of climate change. Moreover, the monitoring of the extension and state of health of the tolares (excluding their extraction as firewood) can be an indicator of the recharge and condition of the aquifers. These potential changes might be recognized and serve for ecosystem monitoring over coming decades.

No assessments of habitat conservation have been made in Bolivia, unlike in other parts of the world (Janssen et al. 2016). The vegetation of the tolares is highly susceptible to various predominantly anthropogenic factors such as overgrazing, excessive exploitation for firewood, and clearing to grow quinoa (VMMAyA 2012). The tola (Parastrephia lepidophylla) is itself considered threatened due to its overexploitation for firewood (Navarro et al. 2012a; VMMAyA 2012), while tolillares shrublands serve as a habitat for endangered species including several Altiplano cacti such as Trichocereus tarijensis, which is considered vulnerable (Navarro \& De la Barra 2012). Other important species in the dry Bolivian Altiplano plant landscape are also endangered, as are the cases of Parastrephia quadrangularis and Lampayo castellani which are considered vulnerable (Navarro et al. 2012b, 2012c).

\section{Author contributions}

G.N. planned the research, conducted the field sampling and identified the plant species, J.A.M. performed the statistical analyses, and both authors participated in discussion of the results and the writing of the manuscript.

\section{References}

Argollo, J. 1994. Geología del Plio-Cuaternario de Bolivia. UMSA-ORSTOM, La Paz, BO.

Beck, S.G. 1985. Flórula ecológica en Bolivia. 1: Puna semiárida en el altiplano boliviano. Ecología en Bolivia 6: 1-41.
Botta-Dukát, Z., Chytrý, M., Hájková, P. \& Havlová, M. 2005. Vegetation of lowland wet meadows along a climatic continentality gradient in central Europe. Preslia 77: 89-111.

Braun-Blanquet, J. 1979. Fitosociología. Bases para el estudio de las comunidades vegetales. Ediciones Blume, Madrid, ES.

Cabrera, A.L. 1957. La vegetación de la Puna Argentina. Revista de Investigaciones Agrícolas. Buenos Aires 11: 217-242.

Cabrera, A.L. 1971. Fitogeografía de la República Argentina. Boletín de la Sociedad Argentina de Botánica 14: 1-42.

Cabrera, A.L. 1994. Regiones Fitogeográficas Argentinas. In: Kugler, W.F. (ed.) Enciclopedia Argentina de Agricultura y Jardinería, Tomo II, Fascículo 1, pp. 1-85. Editorial Acme, Buenos Aires, AR.

Chepstow-Lusty, A., Bush, M.B., Frogley, M.R., Baker, P.A., Paul, A., Fritz, C., Sherilyn, C. \& Aronson J. 2005. Vegetation and climate change on the Bolivian Altiplano between 108,000 and 18,000 yr ago. Quaternary Research 63: 90-98.

Chytrý, M., Tichý, L., Holt, J. \& Botta-Dukát, Z. 2002. Determination of diagnostic species with statistical fidelity measures. Journal of Vegetation Science 13: 79-90.

Fick, S.E. \& Hijmans, R.J. 2017. Worldclim 2: New 1-km spatial resolution climate surfaces for global land areas. International Journal of Climatology 37: 4302-4315.

Fries, R.E. 1905. Zur Kenntnis der alpinen Flora in nördlichen Argentinien. Nova acta Regiae Societatis Scientiarum Upsaliensis Ser. 41: 1-205.

García, E. \& Beck, S.G. 2006. Puna. In: Moraes, M., Øllgaard, B., Kvist, L.P., Borchsenius F. \& Balslev, H. (eds.) Botánica Económica de los Andes Centrales, pp. 51-76. Universidad Mayor de San Andrés, La Paz, BO.

GEOBOL. 1994. Carta Geológica de Bolivia escala 1:100 000. Publicación SGB serie I-CGB-28. Servicio Geológico de Bolivia \& Swedish Geological AB.

Ibisch, P.L., Beck, S.G., Gerkmann, B. \& Carretero, A. 2003. Ecoregiones y ecosistemas. In: Ibisch, P.L. \& Mérida, G. (eds.) Biodiversidad: La Riqueza de Bolivia. Estado de Conocimiento y Conservación, pp. 47-88. Editorial FAN, Santa Cruz de la Sierra, BO.

Janssen, J.A.M., Rodwell, J.S., García Criado, M., Gubbay, S., Haynes, T., Nieto, A., Sanders, N., Landucci, F., Loidi, J., (...) \& Gubbay, S. 2016. European Red List of Habitats. Part 2: Terrestrial and Freshwater Habitats. European Commission, Brussels, BE.

Jennings, M.D., Faber-Langendoen, D., Loucks, O.L., Peet, R.K. \& Roberts, D. 2009. Standards for associations and alliances of the U.S. National Vegetation Classification. Ecological Monographs 79: 173-199.

Lara, R. \& Alzérreca, H. 1982. Contribuciones al conocimiento de la vegetación de las tierras altas de Bolivia. Ministerio Asuntos Campesinos y Agropecuarios (MACA)-Instituto $\mathrm{Na}$ cional de Fomento Lanero (INFOL). Estudios Especializados 32: 1-62.

Li, J., Xiong, G., Xu, W. \& Xie, Z. 2016. Distribution of shrublands in relation to soil and climate in mid-subtropical China. Journal of Plant Ecology 9: 393-401.

Luebert, F. \& Gajardo, R. 2000. Vegetación de los Andes áridos del norte de Chile. Lazaroa 21: 111-130.

Luebert, F. \& Gajardo, R. 2005. Vegetación altoandina de Parinacota (norte de Chile) y una sinopsis de la vegetación de la Puna meridional. Phytocoenologia 35: 79-128.

Martínez Carretero, E. 1995. La puna argentina: delimitación general y división en distritos florísticos. Boletín de la Sociedad Argentina de Botánica 31: 27-40.

Navarro, G. 1993. Vegetación de Bolivia: el Altiplano meridional. Rivasgodaya 7: 69-98. 
Navarro, G. 2002. Vegetación y unidades biogeográficas de Bolivia. In: Navarro, G. \& Maldonado, M. (eds.) Geografía Ecológica de Bolivia. Vegetación y Ambientes Acuáticos, pp. 1-500. Fundación Simón I. Patiño, Cochabamba, BO.

Navarro, G. 2011. Clasificación de la vegetación de Bolivia. Editorial Centro de Ecología Difusión Simón I. Patiño, Santa Cruz de la Sierra, BO.

Navarro, G. \& De la Barra, N. 2012. Trichocereus tarijensis (Vaupel) Werderm. In: Libro Rojo de la Flora Amenazada de Bolivia. Vol. I. Zona Andina, pp 108-109. Ministerio de Medio Ambiente y Agua, La Paz, BO

Navarro, G., Molina, J.A. \& De la Barra, N. 2005. Classification of the high-Andean Polylepis forests in Bolivia. Plant Ecology 176: 113-130.

Navarro, G., De la Barra, N., Meneses, R.I., García, E., Torrico, L., Zeballos M. \& Ferreira, W. 2012a. Parastrephia lepidophylla (Wedd.) Cabrera. In: Libro Rojo de la Flora Amenazada de Bolivia. Vol. I. Zona Andina, pp 95-96. Ministerio de Medio Ambiente y Agua, La Paz, BO.

Navarro, G., De la Barra, N., Meneses, R.I., García, E., Torrico, L., Zeballos M. \& Ferreira, W. 2012b. Parastrephia quadrangularis (Wedd.) Cabrera. In: Libro Rojo de la Flora Amenazada de Bolivia. Vol. I. Zona Andina, pp. 96-97. Ministerio de Medio Ambiente y Agua, La Paz, BO.

Navarro, G., De la Barra, N., Meneses, R.I., García, E., Torrico, L., Zeballos M. \& Ferreira, W. 2012c. Lampayo castellani Moldenke. In: Libro Rojo de la Flora Amenazada de Bolivia. Vol. I. Zona Andina, pp. 86-87. Ministerio de Medio Ambiente y Agua, La Paz, BO.

Olson, D.M. \& Dinerstein, E. 1998. The global 200: A representation approach to conserving the Earth's most biologically valuable ecoregions. Conservation Biology 12: 502-515.

Rigoberto, A.L., Monasterio, M. \& Terceros, L.F. 2007. Regímenes climáticos del altiplano sur de Bolivia: una región afectada por la desertificación. Revista Geográfica Venezolana 48: 11-32.
Rivas-Martínez, S., Rivas Sáenz, S. \& Penas, A. 2011. Worldwide bioclimatic classification system. Global Geobotany 1: $1-634$.

Ruthsatz, B. 1977. Pflanzengesellschaften und ihre Lebensbedingungen in den Andinen Halbwüsten Nordwest-Argentiniens. Dissertationes Botanicae 39: 1-168.

Sánchez-Saldías, A. \& Fariña, R.A. 2014. Palaeogeographic reconstruction of Minchin palaeolake system, South America: The influence of astronomical forcing. Geoscience Frontiers 5: 249-259.

Suárez-Soruco, R. 2000. Compendio de Geología de Bolivia. Revista Técnica de YPFB 18: 1-144.

Tichý, L. 2002. JUICE, software for vegetation classification. Journal of Vegetation Science 13: 451-453.

Tovar, C., Arnillas, C.A., Cuesta, F. \& Buytaert, W. 2013. Diverging responses of tropical Andean biomes under future climate conditions. PLOS ONE 8(5): e63634. doi:10.1371/ journal.pone. 0063634 .

Urrutia, R. \& Vuille, M. 2009. Climate change projections for the tropical Andes using a regional climate model: Temperature and precipitation simulations for the end of the $21 \mathrm{st}$ century. Journal of Geophysical Research: Atmospheres 114: 2156-2202.

USDA 2017. Soil Survey Manual. Handbook No. 18. United States Department of Agriculture, US.

Van der Maarel, E. 1979. Transformation of cover abundance values in phytosociology and its effects on community similarity. Vegetatio 39: 97-114.

Vicente-Serrano, S.M., Kenawy, A.E., Azorín-Molina, C., Chura, O., Trujillo, F., Aguilar, E., Martín-Hernández, N., López-Moreno, J.I., Sánchez-Lorenzo, A., (...) \& Friend, F. 2016. Average monthly and annual climate maps for Bolivia. Journal of Maps 12: 295-310.

VMMAyA (Viceministerio de Medio Ambiente y Agua) 2012. Libro Rojo de la flora amenazada de Bolivia, Vol I - Zona Andina. Ministerio de Medio Ambiente y Agua, La Paz, BO.

\section{Author addresses}

Navarro, G. (gonzalonavarrosanchez@gmail.com)1 \& Molina, J.A. (Corresponding author: jmabril@ucm.es)²

${ }^{1}$ Unidad Académica Regional Cochabamba, Carrera de Ingeniería Ambiental, Universidad Católica Boliviana «San Pablo», Cochabamba, Bolivia

${ }^{2}$ Departamento de Biodiversidad, Ecología y Evolución, Facultad de Ciencias Biológicas, Universidad Complutense de Madrid, c/ José Antonio Novais, 12, 28040-Madrid, Spain

\section{Electronic supplement}

Supplementary material associated with this article is embedded in the pdf of this article. The online version of Phytocoenologia is hosted at the journal's website http://www.schweizerbart.com/journals/phyto/. The publisher does not bear any liability for the lack of usability or correctness of supplementary material.

Supplement S1: Relevé data in Veg-X format.

Please save the electronic supplement contained in this pdf-file by clicking the blue frame above. After saving rename the file extension to .zip (for security reasons Adobe does not allow to embed .exe, .zip, .rar etc. files). 